\title{
Article \\ In Vitro Cytotoxicity of Trastuzumab (Tz) and Se-Trastuzumab (Se-Tz) against the Her/2 Breast Cancer Cell Lines JIMT-1 and BT-474
}

\author{
Priyanka Bapat ${ }^{1}$, Debalina Goswami Sewell ${ }^{1}$, Mallory Boylan ${ }^{1}$, Arun K. Sharma ${ }^{2}$ and Julian E. Spallholz ${ }^{1, *}$ \\ 1 Nutritional Sciences, College of Human Sciences, Texas Tech University, Lubbock, TX 79409, USA; \\ bapat.priyanka@gmail.com (P.B.); goswami.rima1985@gmail.com (D.G.S.); malloryboylan1@gmail.com (M.B.) \\ 2 Department of Pharmacology, Penn State Cancer Institute, CH72, Penn State College of Medicine, \\ 500 University Drive, Hershey, PA 17033, USA; aks14@psu.edu \\ * Correspondence: spallholz@aol.com; Tel.: +1-806-786-8349
}

check for updates

Citation: Bapat, P.; Sewell, D.G.; Boylan, M.; Sharma, A.K.; Spallholz, J.E. In Vitro Cytotoxicity of

Trastuzumab (Tz) and

Se-Trastuzumab (Se-Tz) against the Her/2 Breast Cancer Cell Lines JIMT-1 and BT-474. Int. J. Mol. Sci. 2021, 22, 4655. https://doi.org/ 10.3390/ijms22094655

Academic Editor: Giovanni Natile

Received: 25 March 2021

Accepted: 22 April 2021

Published: 28 April 2021

Publisher's Note: MDPI stays neutral with regard to jurisdictional claims in published maps and institutional affiliations.

Copyright: (c) 2021 by the authors. Licensee MDPI, Basel, Switzerland. This article is an open access article distributed under the terms and conditions of the Creative Commons Attribution (CC BY) license (https:// creativecommons.org/licenses/by/ $4.0 /)$.

\begin{abstract}
Her/2+ breast cancer accounts for 25\% mortality in women and overexpression of Her $/ 2$ leads to cell growth and tumor progression. Trastuzumab $(\mathrm{Tz})$ with Taxane is the preferred treatment for Her/2+ patients. However, Tz responsive patients often develop resistance to $\mathrm{Tz}$ treatment. Herein, redox selenides (RSe-) were covalently linked to Tz using a selenium (Se)-modified BoltonHunter Reagent forming Seleno-Trastuzumab (Se-Tz; $25 \mu \mathrm{gSe} / \mathrm{mg}$ ). Se-Tz was compared to Tz and sodium selenite to assess the viability of JIMT-1 and BT-474 cells. Comparative cell viability was examined by microscopy and assessed by fluorometric/enzymatic assays. Se-Tz and selenite redox cycle producing superoxide $\left(\mathrm{O}_{2}{ }^{\bullet-}\right)$ are more cytotoxic to Tz resistant JIMT- 1 and Tz sensitive BT-474 cells than Tz. The results of conjugating redox selenides to Tz suggest a wider application of this technology to other antibodies and targeting molecules.
\end{abstract}

Keywords: human epidermal growth factor receptor 2 (Her/2); epidermal growth factor receptor (EGFR); selenium (Se); antibody drug conjugate (ADC); monoclonal antibody (mab); Herceptin ${ }^{\circledR}$; Trastuzumab (Tz); Kadcyla ${ }^{\circledR}(\mathrm{T}-\mathrm{DM}-1)$; superoxide $\left(\mathrm{O}_{2}{ }^{\bullet-}\right)$; reduced glutathione $(\mathrm{GSH})$

\section{Introduction}

In 1978, Carpenter et al. discovered Epidermal Growth Factor Receptor 1 (EGFR 1) [1]. Following the discovery of EGFR 1, a group of scientists at the Massachusetts Institute of Technology (MIT) discovered the "neu" gene, known as Human Epidermal Growth Factor Receptor 2 (Her/2). Her/2 encodes a $185 \mathrm{kD}$ transmembrane glycoprotein, a member of the family of EGFR receptors. The EGFR family comprises four homologous receptorsErbB-1/Her/1/EGFR [2], ErbB-2/Her/2/neu [3], ErbB-3/Her/3 [4], ErbB-4/Her/4 [5]. These receptors have two cysteine rich binding sites, a transmembrane lipophilic segment and an intracellular tyrosine kinase domain [6]. Self-activation of these receptors by either homo- or heterodimerization initiates the complex downstream signaling cascade and cell division. All the receptors except Her/2 bind EGFR via the extracellular domains but it is preferential dimerization that initiates cell division [7]. Normal breast cells express $\sim 20,000 \mathrm{Her} / 2$ receptors / cell, whereas cancer cells have $>100 \mathrm{X}$ the expression of the Her $/ 2$ receptors/cell. Blocking dimerization and signal transduction was viewed as a therapeutic approach to treat Her/2+ breast cancer. The selected blocking dimerization agent for Her/ 2 was a monoclonal antibody, Trastuzumab (Tz), generated and further developed by Slamon [8,9] and made commercially and clinically available by scientists at Genentech, South San Francisco, CA [10]. In September 1998, the US FDA approval was granted for Tz, Herceptin ${ }^{\circledR}$ treatment of Her $/ 2+$ breast cancer [11]. This Tz drug resistance is clinically prevalent in Her/2+ patients, and Genentech has sought to remedy the resistance by covalently attaching emtansine, a cytoskeletal inhibitor to Tz, forming the ADC, Kadcyla ${ }^{\circledR}$ 
(T-DM-1). This ADC was clinically approved for treating patients with $\mathrm{Tz}$ resistance and metastasis in February, 2013 [12].

This is the first research that reports the development of a redox selenium (Se) containing $\mathrm{ADC}$ of $\mathrm{Tz}$ and its therapeutic in vitro comparison to $\mathrm{Tz}$ against Herceptin ${ }^{\circledR}$ resistant and Herceptin ${ }^{\circledR}$ sensitive breast cancer cell lines. We covalently attached redox Se to $\mathrm{Tz}$ via a modified Se-containing Bolton-Hunter [13] reagent followed by exhaustive dialysis. Unlike $\mathrm{Tz}$, Se-Tz generates superoxide $\left(\mathrm{O}_{2}{ }^{\bullet-}\right)$, as measured in vitro or ex vivo, by oxidation of reduced glutathione (GSH) and other thiols and one-electron reduction, as described by Chaudière et al. [14]. Selenite, known for its concentration dependent toxicity to all cells by also generating $\mathrm{O}_{2}{ }^{\bullet-}$ from GSH oxidation, as described by Seko et al. [15], was congruently compared to the cytotoxicity of Tz and the ADCs against the Tz resistant JIMT- 1 and Tz sensitive BT-474 cell lines (Figure 1) over both concentration and time variables assessed by photographic, fluorescent and enzymatic assays of cell viability.
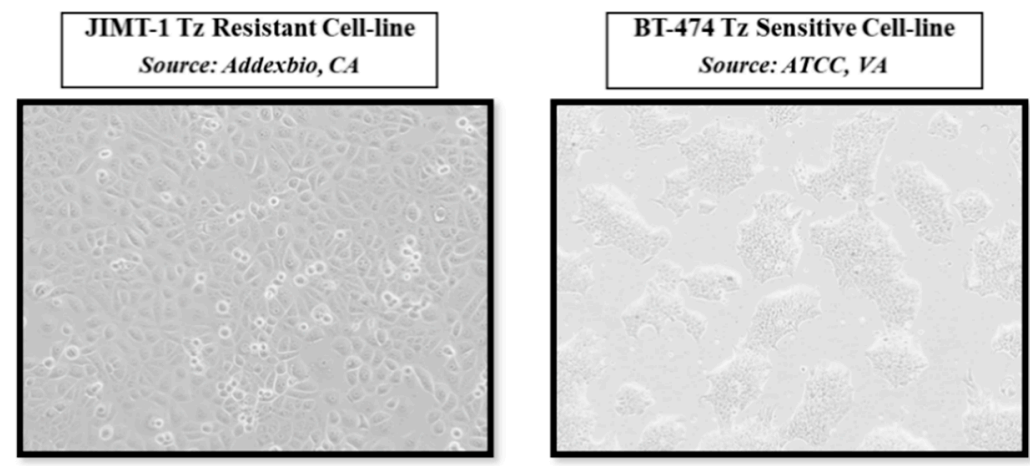

Figure 1. Original morphology of Se-Trastuzumab treated JIMT-1, Trastuzumab resistant and BT-474, Trastuzumab sensitive cell lines. Doubling cell division times for JIMT-1 and BT-474 cells were approximately 30 and $100 \mathrm{~h}$, respectively.

\section{Results}

\subsection{Selenium Conjugation of Trastuzumab with the Se-Modified Bolton-Hunter Reagent}

The colorless Tz clinical antibody, Herceptin ${ }^{\circledR}$, following redox Se conjugation by the red colored Se-Bolton-Hunter Reagent (Se-BHR) (Figure 2a,b) in pH 8.5 borate buffer produced an orange colored Tz antibody as shown in Figure 2c. The mabs were subjected to exhaustive dialysis in PBS buffer, $\mathrm{pH}$ 7.4, and Se conjugation to Tz was then analyzed by inductively coupled plasma mass spectrometry (ICP-MS) by TraceAnalysis, Inc., Lubbock, TX. The Se concentration for dialyzed Se-Tz was calculated to be $25.8 \mu \mathrm{gSe} / \mathrm{mg}$ protein after $72 \mathrm{~h}$ of conjugation in borate buffer and the control $\mathrm{Tz}$ Se concentration was calculated to be $<0.35 \mu \mathrm{gSe} / \mathrm{mg}$ (Figure 3).

a

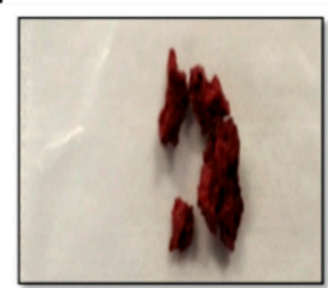

b

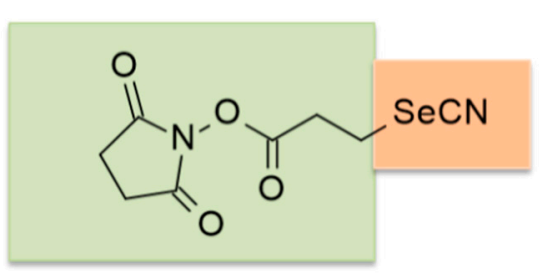

C

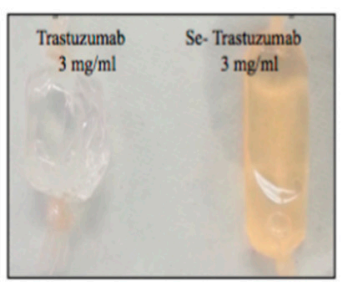

Figure 2. (a) Se-BHR: selenium conjugating Bolton-Reagent; (b) chemical structure of Se-BHR; (c) control and selenium labeled $\mathrm{Tz}$ following exhaustive dialysis, $\mathrm{pH}$ 7.4. 
a

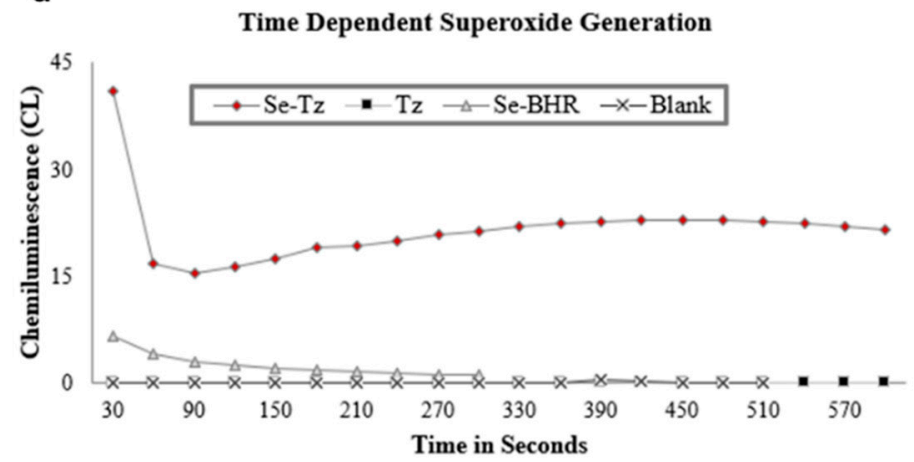

b

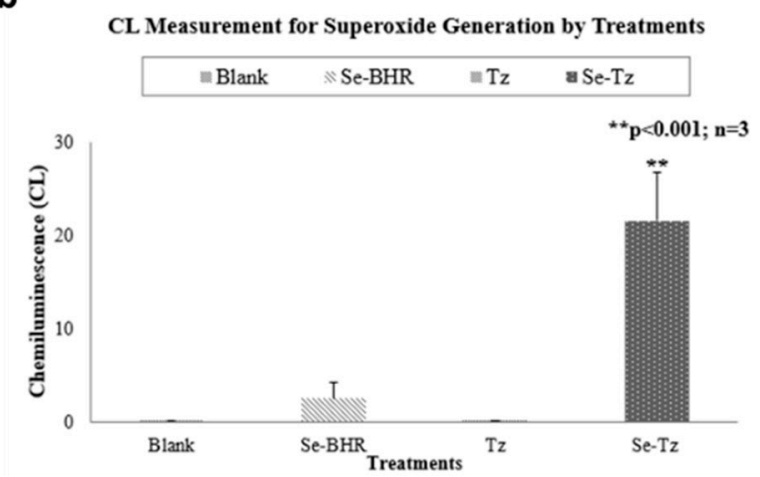

Figure 3. (a) $\mathrm{O}_{2}{ }^{\bullet-} \mathrm{CL}$ generated by treatments over time. Figure (b) is the sum total of $\mathrm{O}_{2}{ }^{\bullet-} \mathrm{CL}$ generated by each of the treatments over $5 \mathrm{~min}$. For the measurement of superoxide generation, $330 \mu \mathrm{L}$ of Se-Tz was added to $500 \mu \mathrm{L}$ of CL cocktail and similar steps were followed for the native Tz $(330 \mu \mathrm{L})$ and Se-BHR $(50 \mu \mathrm{L})$ in PBS. Mean CL generation by Se-BHR $(20 \mathrm{mg} / \mathrm{mL}$ ), Tz (protein concentration $3 \mathrm{mg} / \mathrm{mL}$ ) and Se-Tz (protein concentration $3 \mathrm{mg} / \mathrm{mL}$ ) was $2.53 \pm 1.68,0.05 \pm 0.036$ and $21.5 \pm 5.17$ CLU (** $p<0.001)$, respectively.

\subsection{Chemiluminescence (CL) Assay}

Generation of $\mathrm{O}_{2}{ }^{\bullet-}$ by Se-Tz and Tz was measured in vitro by a Lucigenin CL assay. In the presence of GSH, inorganic selenite, but not selenate, also generates superoxide as first reported by Seko et al. and later in 1991, Yan et al. showed the generation of $\mathrm{O}_{2}{ }^{\bullet-}$ by various organic selenium compounds in the presence of GSH and other thiols [16,17]. In this study, we labeled Tz (Herceptin ${ }^{\circledR}$ ) with reduceable selenides $\left(\mathrm{RSe}^{-}\right.$) using a Se-BHR and report the redox cycling by Se-Tz but not Tz in the presence of GSH at $37^{\circ} \mathrm{C}$ in Figure 3.

\subsection{Visual Assessment of the Morphological Changes in JIMT-1 and BT-474 Cell Lines Following Treatments}

JIMT-1 and BT-474 cells (Figure 1) were seeded at a density of $1 \times 10^{5}$ cells/well in 24-well plates and were treated with Se-Tz at 4.8 and $19.2 \mu \mathrm{gSe} /$ well, Tz dose was matched to the equal volume of the highest dose of Se-Tz treatment and with selenite, $10 \mu \mathrm{gSe} /$ well for 72, 96 and $120 \mathrm{~h}$ at which times cells were photographed at 20X magnification after adding Trypan Blue (Figure 4). The photographs in Figure 4a,b visually demonstrate the increasing cytotoxicity of Se-Tz in both cell lines with increasing concentration (left to right) and with increasing time of treatment (top to bottom). Against both cell lines, the classic dose and time dependency of a toxin was observed-in this case, redox active Se-Tz and sodium selenite. Control and Tz cells photographically show only minor if any differences in comparison to Se treated cells.

\subsection{Superoxide Generation Ex Vivo by DHE: Visual Micrographs and Fluorescence Assay}

JIMT- 1 and BT- 474 cells were seeded at a density of $2 \times 10^{5}$ cells / well in 24-well plates followed by treatment with Tz and 4.8 and $9.6 \mu \mathrm{gSe} /$ well Se-Tz, and selenite, $10 \mu \mathrm{gSe} /$ well. Each well was pretreated with 100 and 50 units of SOD and catalase added to each well, respectively. At $30 \mathrm{~min}$ after treatments, $10 \mu \mathrm{L}$ of DHE, dihydroethidium (Sigma \#D7008), was added and cells were photographed. The red color in Figure $5 \mathrm{a}, \mathrm{b}$ and its intensity are qualitatively and quantitatively indicative of superoxide generation. The fluorescence intensity after photography was measured at an excitation wavelength of $520 \mathrm{~nm}$ and 610 nm emission using the microtiter plate reader (BioTek Synergy H1, Winooski, VT, USA). Photographs of the JIMT- 1 and BT- 474 cells at $4 \mathrm{X}$ and 20X magnification demonstrate the red fluorescence of the $\mathrm{O}_{2}{ }^{\bullet-}$ generated with and without Se treatments. Greater $\mathrm{O}_{2}{ }^{\bullet-}$ generation was observed at the higher concentrations of Se-Tz, $9.6 \mu \mathrm{gSe} /$ well, followed by selenite at $10 \mu \mathrm{gSe} /$ well. After the photographic comparison of Se-Tz induced $\mathrm{O}_{2}{ }^{\bullet-}$ generation by DHE staining, fluorescence was quantitatively measured using spectrophotometry, revealing the comparative quantitative mean fluorescence intensity observed 
photographically. The greater DHE fluorescence intensity of the Se-Tz treated JIMT-1 (Figure 5c) and BT-474 (Figure 5d) cells was consistent with the photographic comparisons. $\mathrm{Se}-\mathrm{Tz}$ at $9.6 \mu \mathrm{gSe} /$ well demonstrated a significant $(p<0.05)$ increase in fluorescence$850 \pm 20$ fluorescent units compared to control cells, $504 \pm 53$ fluorescent units. Native Tz treated cells did not show higher fluorescence intensity as compared to control cells $(p>0.05)$. Selenite treated cells also revealed higher, $661 \pm 73$, DHE fluorescence units, as compared to control, $504 \pm 53$, and native $\mathrm{Tz}, 455 \pm 36$, fluorescent units, which were significantly different $(p<0.05)$. A complete $96-$ well blank with all chemicals added except cells and with identical treatments showed no fluorescence, indicating the fluorescence photographed and fluorometrically measured $\mathrm{O}_{2}{ }^{\bullet-}$ was entirely generated intracellularly.

\section{a JIMT-1 Cells}

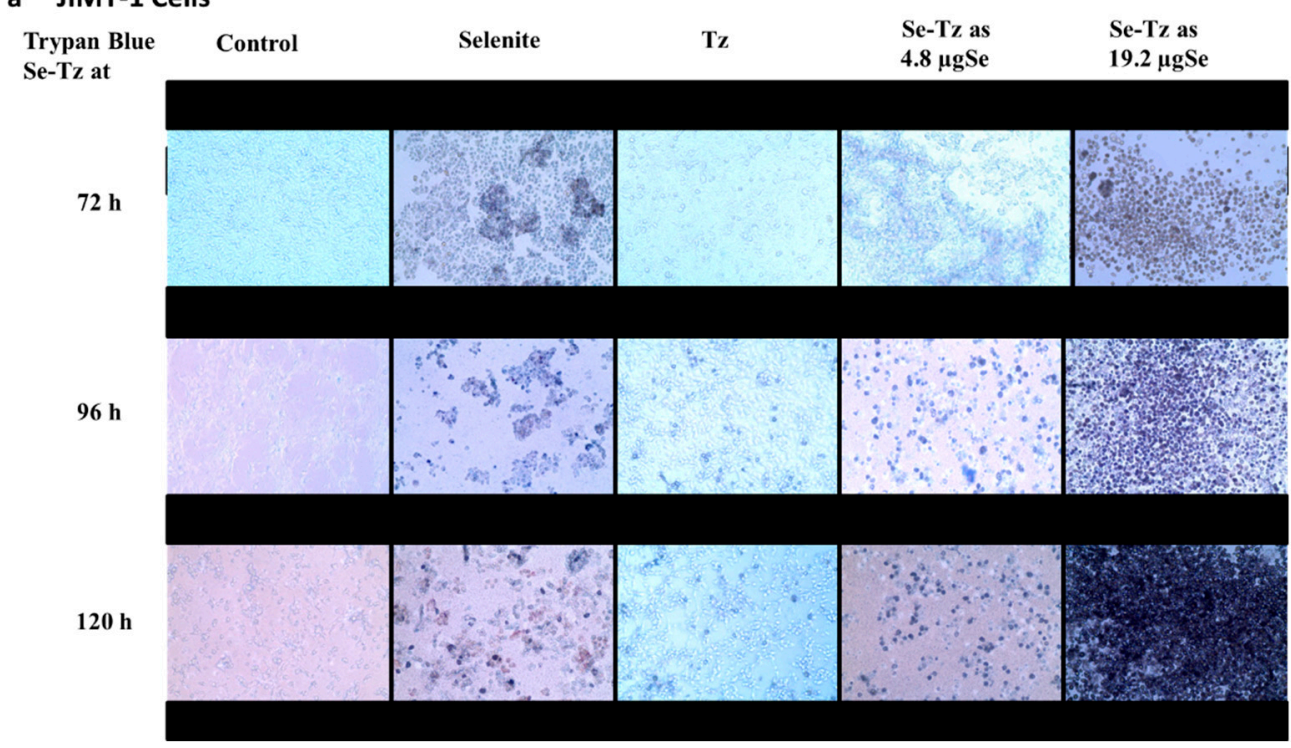

b BT-474 Cells

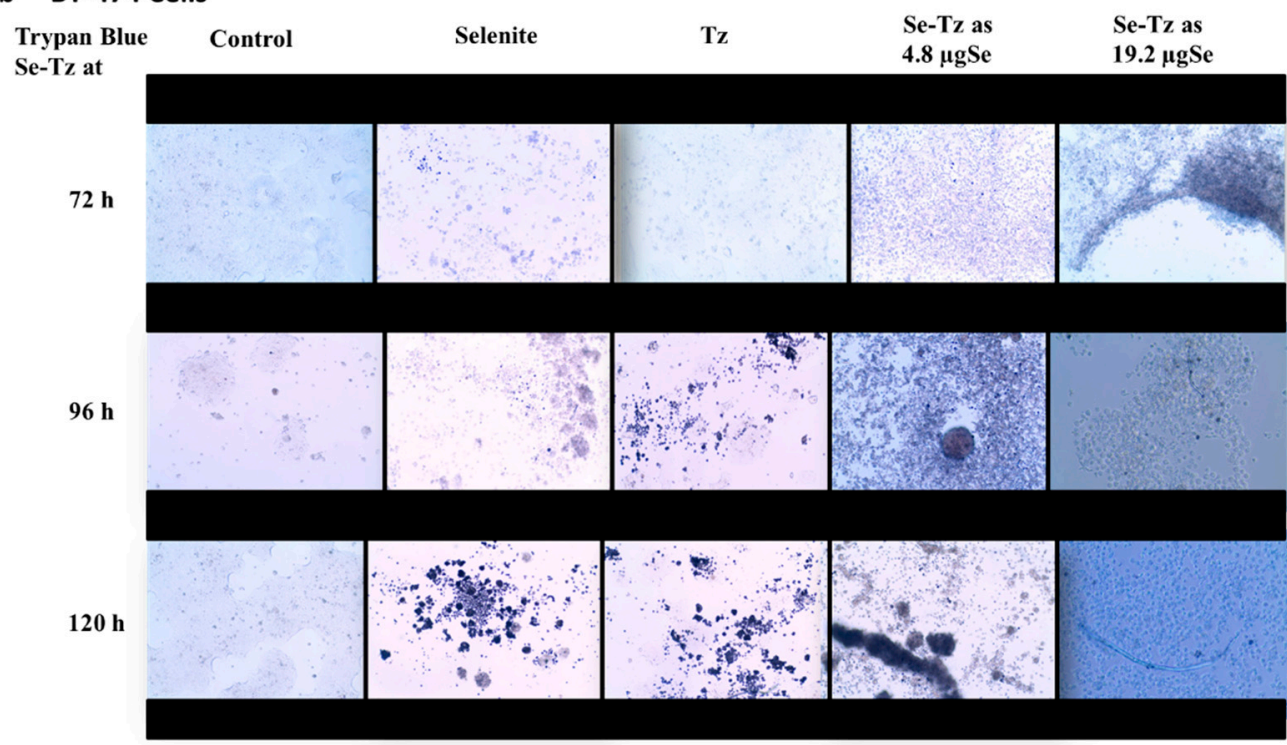

Figure 4. 20X Microphotographs of Trypan Blue Stained Cells after Treatments. (a) JIMT-1 cells photographed at the concentrations and times indicated; (b) BT-474 cells photographed at the concentrations and times indicated. Selenite was used as a redox toxic positive control at a concentration of $10 \mu \mathrm{gSe} /$ well. Selenite at concentrations less than $10 \mu \mathrm{gSe} /$ well had no visible effect on cancer cell lines under these experimental conditions. 
a JIMT-1 Cells

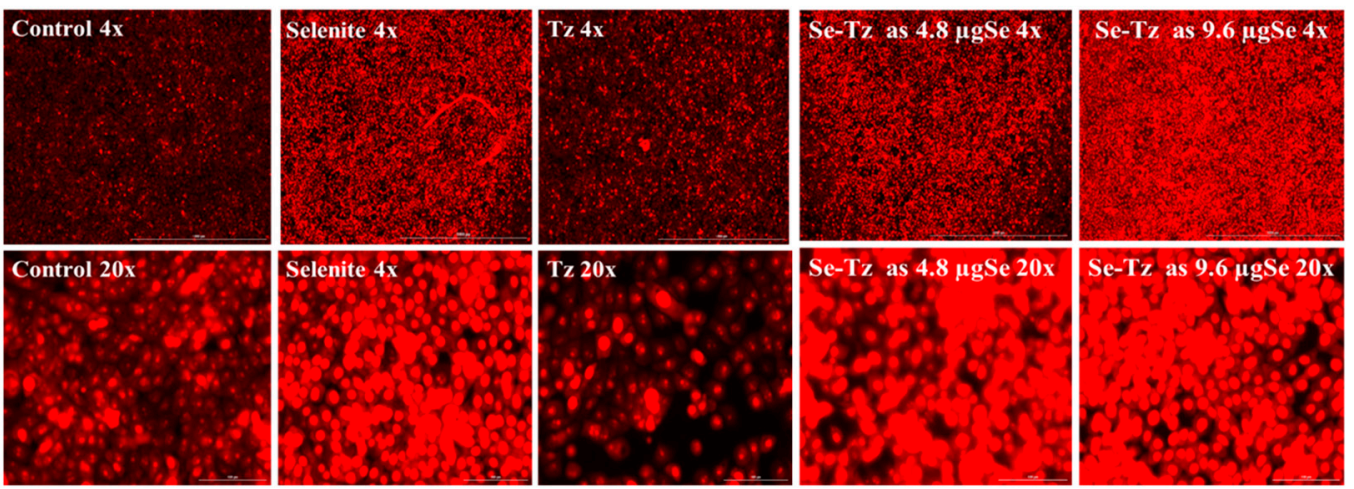

b BT-474 Cells
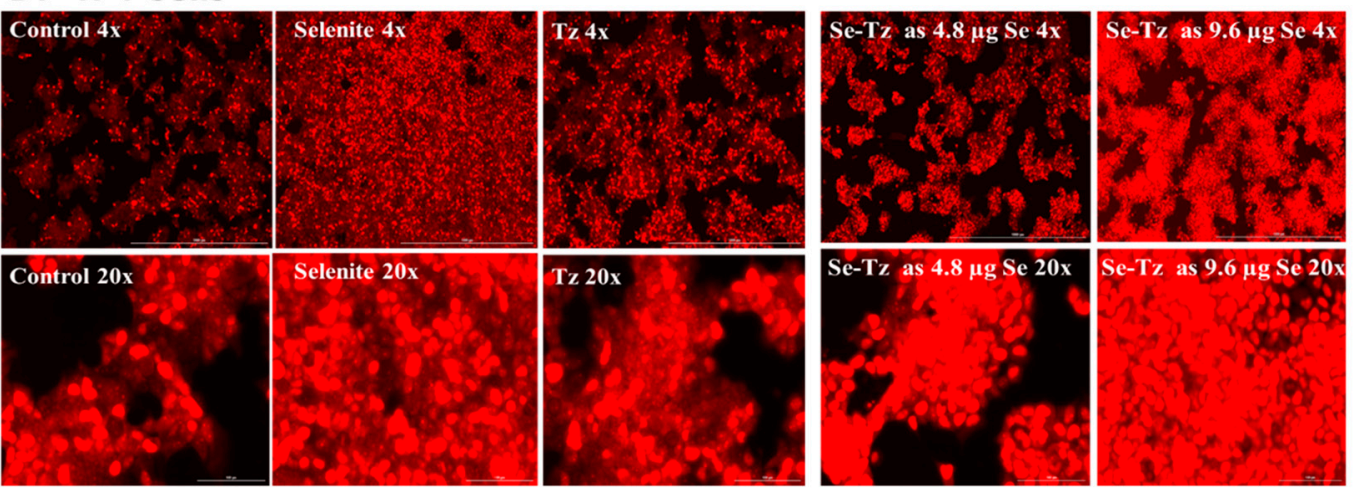

C

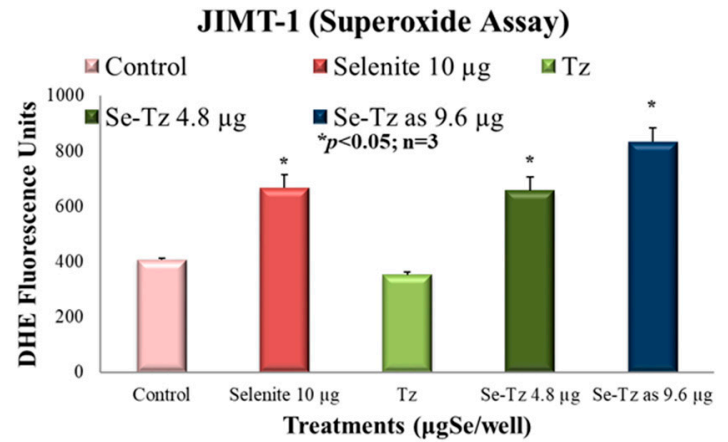

d

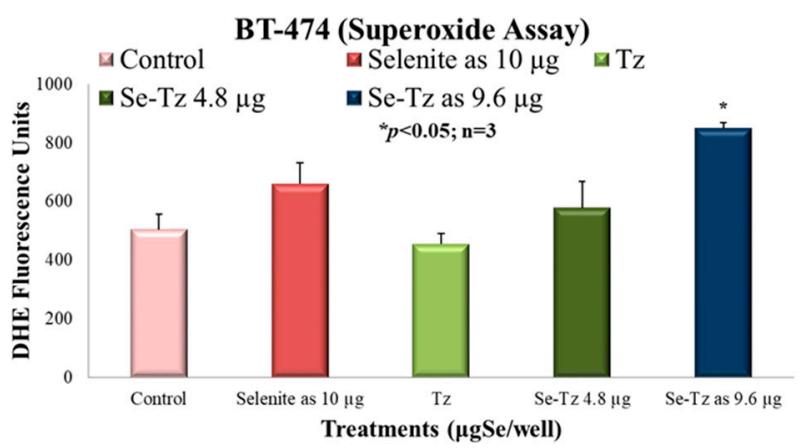

Figure 5. Superoxide Generation by Dihydroethidium (DHE) detection after selenium treatments. (a,b) Photographs of superoxide staining of JIMT-1 \& BT-474 cells after Se treatments at magnifications of 4 X= $1000 \mu \mathrm{m} ; 20 \mathrm{X}=100 \mu \mathrm{m}$; $(\mathbf{c}, \mathbf{d})$ Quantitative measurement of superoxide generation of JIMT-1 \& BT-474 cells after Se treatments. After acclimatization for $24 \mathrm{~h}, 50$ units/well of SOD and 100 units/well of catalase were added to all wells in media. All cells, control, selenite, $\mathrm{Tz}$ and Se-Tz were appropriately treated and then DHE was added to the cells at a final concentration of $10 \mu \mathrm{M}$ in media.

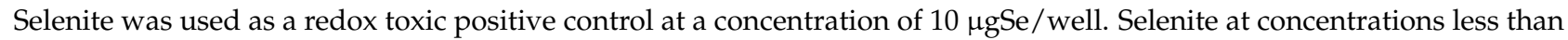
$10 \mu \mathrm{gSe} /$ well had no visible effect on cancer cell lines under these experimental conditions. The fluorescence was measured using a microtiter plate reader with an excitation at $520 \mathrm{~nm}$ and emission at $610 \mathrm{~nm}$.

\section{5. $\mathrm{H}_{2} \mathrm{O}_{2}$ Generation Ex Vivo by Dichlorofluorescein (DCFH-DA): Visual Micrographs}

Following in a manner similar to the one described above for the DHE detection of $\mathrm{O}_{2}{ }^{\bullet-}$, JIMT-1 and BT-474 cells were subjected to dichlorofluorescein (DCFH-DA) staining and treatment with $\mathrm{Tz}$, selenite $(10 \mu \mathrm{gSe} /$ well $)$ and Se-Tz $(4.8 \mu \mathrm{gSe})$ for the detection of hydrogen peroxide $\left(\mathrm{H}_{2} \mathrm{O}_{2}\right)$. Protein concentrations for the Se-Tz and $\mathrm{Tz}$ treatments were the same. The results of the photographic detection of the green fluorescence from the deacetylation of DCFH-DA by a cellular esterase to a nonfluorescent compound is followed by the intracellular ROS oxidation of DCFH-DA to $2^{\prime}, 7^{\prime}$-dichlorofluorescein (DCF), which is highly fluorescent as shown in Figure 6. Assuming that the $\mathrm{H}_{2} \mathrm{O}_{2}$ generated green 
fluorescence observed in Figure 6 from DCFH is derived from the selenium treatments initially generating $\mathrm{O}_{2}{ }^{\bullet-}$ as shown in Figure 5, cellular SOD then generates the $\mathrm{H}_{2} \mathrm{O}_{2}$ from $\mathrm{O}_{2}{ }^{\bullet-}$ with the differences in fluorescence between the two cell lines being striking. JIMT- 1 control and Tz treated cells reveal almost no $\mathrm{H}_{2} \mathrm{O}_{2}$ being generated, while selenite and Se-Tz treated cells result in large amounts of $\mathrm{H}_{2} \mathrm{O}_{2}$ being generated as measured by DCFH-DA (Figure 6a). As suggested from the DHE experiments in Figure 5, JIMT-1 cells are perhaps resistant to $\mathrm{Tz}$, as Tz produces little $\mathrm{O}_{2}{ }^{\bullet-}$ over control cells and any cellular $\mathrm{H}_{2} \mathrm{O}_{2}$ is rapidly converted to water by either catalase or glutathione peroxidase or both, eliminating $\mathrm{Tz}$ toxicity not seen with selenite or Se-Tz treatments (Figure 6a). Unlike the JIMT-1 Herceptin ${ }^{\circledR}$ resistant control cells, the BT-474 Herceptin ${ }^{\circledR}$ sensitive control cells show a greater background $\mathrm{H}_{2} \mathrm{O}_{2}$ generation, which is visually enhanced by selenite, $\mathrm{Tz}$ and $\mathrm{Se}-\mathrm{Tz}$ (Figure $6 \mathrm{~b}$ ). The visual enhancement of $\mathrm{H}_{2} \mathrm{O}_{2}$ by Tz may account for the reported BT-474 cell Herceptin ${ }^{\circledR}$ susceptibility to Tz. Both selenite and Se-Tz visually enhance $\mathrm{H}_{2} \mathrm{O}_{2}$ generation even more and visually change the morphological "island" pattern of the BT-474 control cells, seen in Figures 1 and $6 \mathrm{~b}$, which are "lit up" by the background $\mathrm{H}_{2} \mathrm{O}_{2}$ produced by the control BT- 474 cells. Following photography, fluorescence by DCF activation at 475 and $525 \mathrm{~nm}$ was performed with the microplate reader. The DCF florescence intensity in all but the JIMT-1 control and Tz treated cells was too intense to be quantified by the plate reader and for that reason no quantitative florescence data are reported.
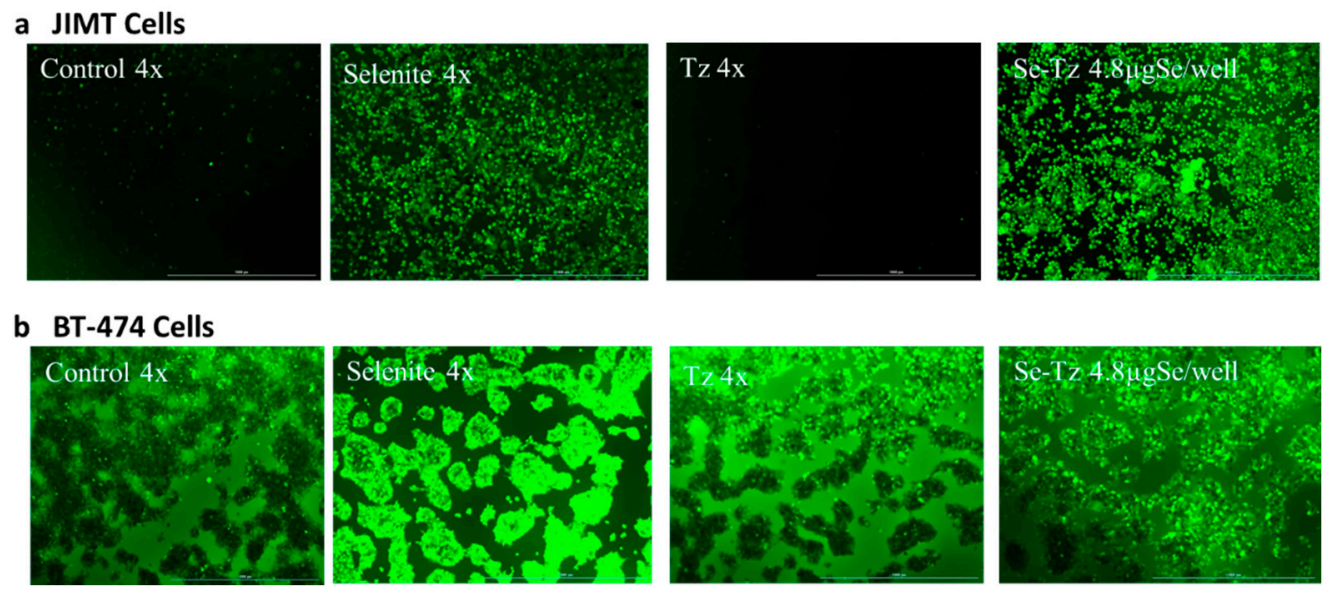

Figure 6. Photographic hydrogen peroxide detection by DCFH-DA after selenium treatments at magnifications of 1000$1010 \mu \mathrm{m}$. (a) Hydrogen peroxide staining of JIMT-1 cells after Se treatments; (b) hydrogen peroxide staining of BT-474 cells after Se treatments. After acclimatization for $24 \mathrm{~h}, 50$ units/well of SOD and 100 units/well of catalase were added to all wells in media. All cells, control, selenite, Tz and Se-Tz were appropriately treated and then DCFH-DA was added to the cells at a final concentration of $30 \mu \mathrm{M}$ in media. Fluorescence intensity was read using a fluorescence microplate reader with an excitation at $475 \mathrm{~nm}$ and emission at $525 \mathrm{~nm}$. Selenite was used as a redox toxic positive control at a concentration of $10 \mu \mathrm{gSe} /$ well. Selenite at concentrations less than $10 \mu \mathrm{gSe} /$ well had no visible effect on cancer cell lines under these experimental conditions.

\subsection{Apoptotic Caspase-3 Activity Assay}

JIMT- 1 cells were seeded at the density of $3 \times 10^{5}$ cells/well in 24 -well plates and then treated with native Tz, Se-Tz at $4.8 \mu \mathrm{gSe} /$ well and selenite, $10 \mu \mathrm{gSe} /$ well for $24 \mathrm{~h}$. Se-Tz treated cells demonstrated a significant $\left({ }^{*} p<0.05\right) 2$-fold increase in caspase-3 activation as compared to native $\mathrm{Tz}$ (Figure 7a). There was no significant increase in caspase-3 in the selenite treated cells compared to control and Tz treated cells. BT-474 cells were seeded at a density of $3 \times 10^{5}$ cells/well in 24-well plates and treated with native Tz, Se-Tz at $4.8 \mu \mathrm{gSe} /$ well and selenite, $10 \mu \mathrm{gSe} /$ well for $72 \mathrm{~h}$. For BT- 474 cells, as indicated by caspase3 units in Figure $7 \mathrm{~b}$, Se-Tz significantly increased caspase- $3\left({ }^{*} p<0.05\right)$ activation by nearly 3 -fold over control cells after $72 \mathrm{~h}$ of incubation. Selenite treated cells increased caspase-3 
activation by 2 -fold as compared to control and native Tz treated cells, but the increase was not significant $-p<0.05$.

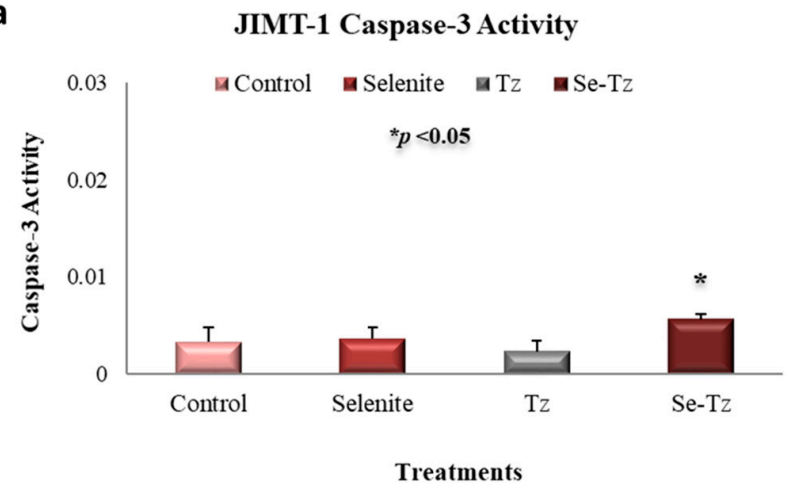

b

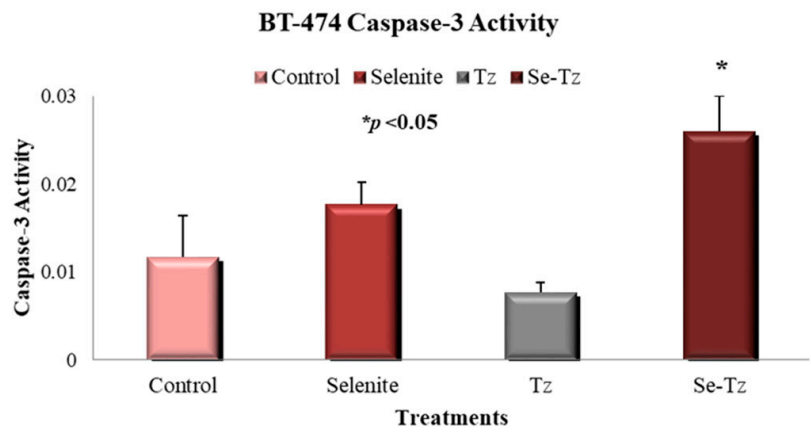

Figure 7. Caspase-3 activity from cell lines after selenium treatments. (a) JIMT-1 cells after $24 \mathrm{~h}$ of Trastuzumab and selenium treatments; (b) BT-474 cells after $72 \mathrm{~h}$ of Trastuzumab and selenium treatments. Cells were treated with Se-Tz at the concentration of $4.8 \mu \mathrm{gSe} /$ well and Tz cells were treated with an equal mab protein concentration. Selenite was used as a redox toxic positive control at a concentration of $10 \mu \mathrm{gSe} /$ well. Selenite at concentrations less than $10 \mu \mathrm{gSe} / \mathrm{well}$ had no visible effect on cancer cell lines under these experimental conditions.

\subsection{Cell Viability with the MTT Assay}

The MTT assay was used as a supportive measure of cell viability of control cells and Se toxicity as assessed by Trypan Blue exclusion photographically in Figure 4 . Both cell lines, the Tz Herceptin ${ }^{\circledR}$ resistant JIMT-1 and Tz Herceptin ${ }^{\circledR}$ sensitive BT-474 cells, were seeded at a density of $1 \times 10^{5}$ cells and treated with two different concentrations of Se-Tz; 2.4 and $4.8 \mu \mathrm{gSe} /$ well; as well as Tz and selenite, $10 \mu \mathrm{gSe} /$ well. To ascertain the effect of time, cells were incubated post-treatments for 72, 96 and $120 \mathrm{~h}$ (Figure $8 \mathrm{a}, \mathrm{b}, \mathrm{d}$ ). The cytotoxic effect of Se-Tz on cell viability was demonstrable in a dose and time dependent manner in both cell lines. At the highest concentration tested, Se-Tz at $4.8 \mu g S e$ /well induced a significant decrease in the proliferation rate of the Tz resistant JIMT- 1 cell line $(* * p<0.001)$ as compared to the Tz treated and control cells (Figure 8a). It was also interesting to observe the time dependent effect on the cell proliferation at $120 \mathrm{~h}$, for upon treatment Se-Tz with $2.4 \mu \mathrm{gSe} /$ well and $4.8 \mu \mathrm{gSe} /$ well, loss of cell viability was nearly equivalent. Tz treated JIMT-1 cells did not show any significant $(p>0.05)$ reduction in cell viability in accordance with the known Tz resistance of the JIMT-1 cells [18] Selenite at $10 \mu \mathrm{gSe} /$ well revealed cell viability to be less than $35 \%$ after 72,96 and $120 \mathrm{~h}$ of incubation. JIMT-1 cells were also found to be more susceptible to selenite toxicity as compared to the Tz sensitive BT-474 cells. The Tz sensitive BT-474 cells demonstrated reduction in cell viability only at the highest concentration of Se-Tz tested-4.8 $\mu \mathrm{gSe} /$ well-in a time dependent manner, as shown in Figure $8 \mathrm{~b}$. An actual increase in the rate of cellular proliferation at lower concentrations of Se-Tz, less than $2.4 \mu \mathrm{gSe} /$ well, was observed, demonstrating some Se resistance. Selenite at $10 \mu \mathrm{gSe} /$ well significantly $(p>0.001)$ reduced cell viability of both cell lines to less than $10 \%$ to that of control cells. The susceptibility of treatments of the two cell lines by Se-Tz were different (Figure 9). This was seen in the calculation of both cell lines, JIMT-1 (0.310) and BT-474 (3.03). Graph pad prism software was used to calculate the $\mathrm{IC}_{50}$ values of Se-Tz treatments of the two cell lines. Graphical depiction of the $\mathrm{IC}_{50}$ was performed using the Microsoft Excel, 2007, software. 


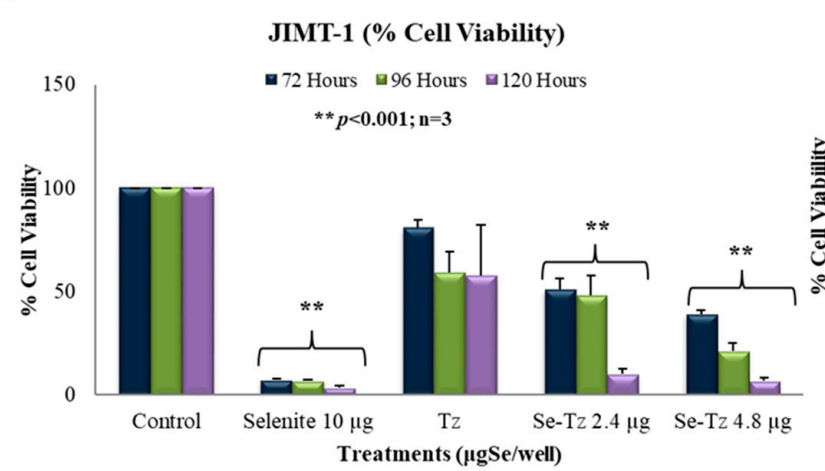

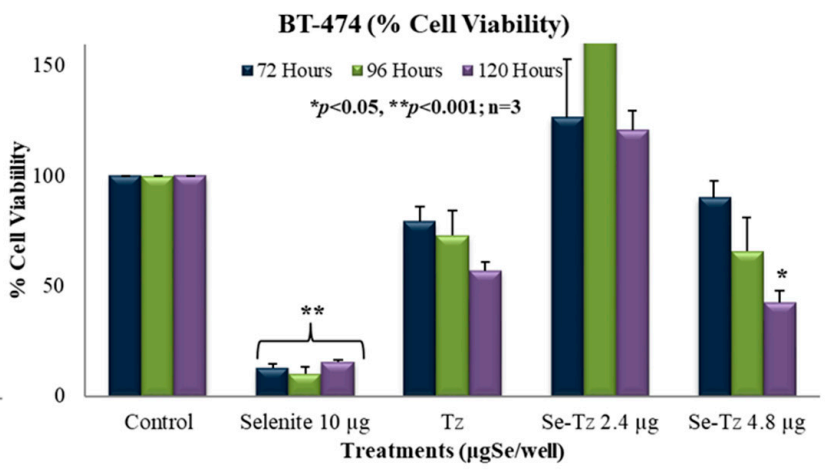

C

d

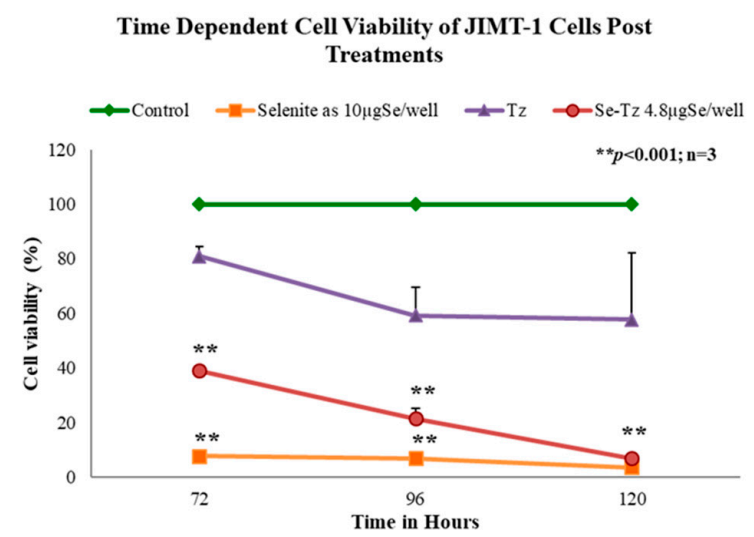

Time Dependent Cell Viability of BT-474 Cells Post Treatments

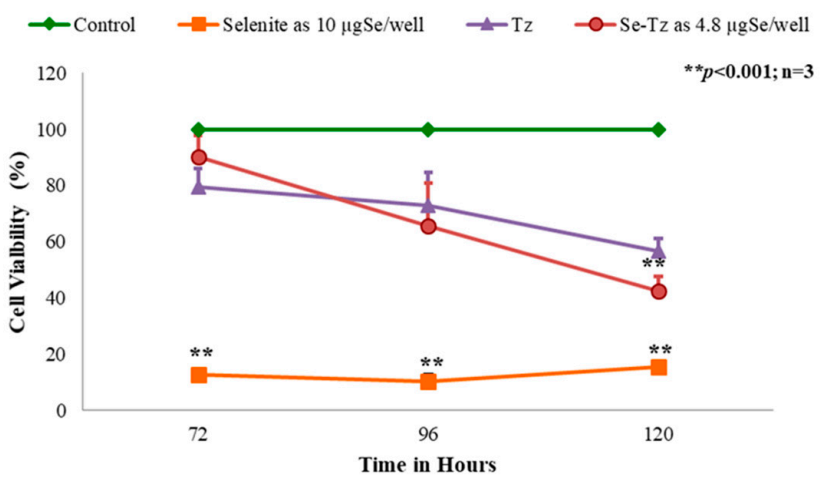

Figure 8. Cells were treated with Se-Tz at the concentrations of 2.4 and $4.8 \mu \mathrm{gSe} /$ well and Tz cells were treated with an equal mab protein concentration. Selenite was used as a redox toxic positive control at a concentration of $10 \mu \mathrm{gSe} /$ well with significant decrease in \% cell viability. MTT cell viability assay demonstrated significant decrease in \% cell viability in Se-Tz treated JIMT-1 cells (a) and BT-474 cells (b) in a time and dose dependent manner compared to control cells. Se-Tz at $2.4 \mu \mathrm{gSe} /$ well concentration up-regulated \% cell viability of BT-474 cells (b). Figure 8 (c,d) represent the time dependent decrease in \% cell viability of JIMT-1 and BT-474 cells, respectively, of Se-Tz treated cells at the concentration of $4.8 \mu \mathrm{gSe} /$ well and selenite at $10 \mu \mathrm{gSe} /$ well compared to control cells. Tz cells were treated with an equal mab protein concentration. Selenite at concentrations less than $10 \mu \mathrm{gSe} /$ well had no visible effect on both the cancer cell lines under these experimental conditions.

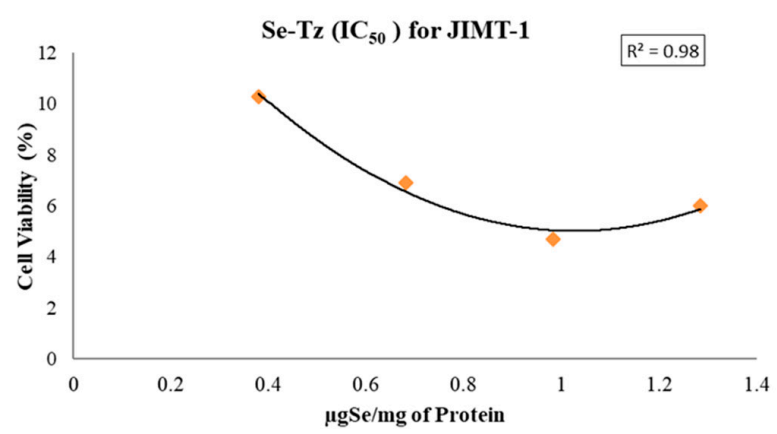

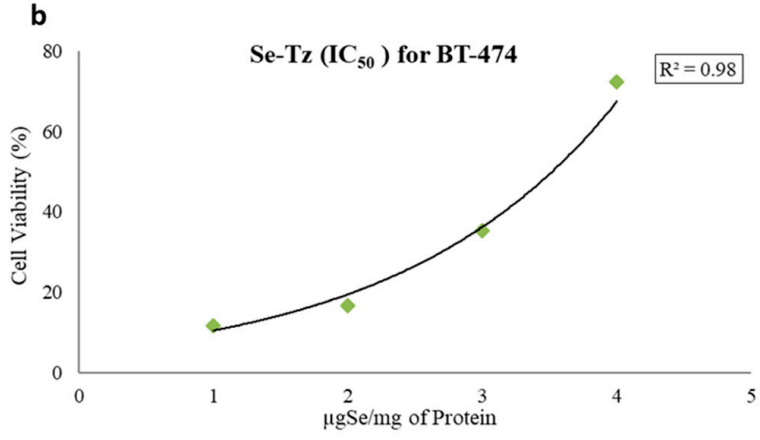

C

\begin{tabular}{|c|c|}
\hline Cell line & $\mathrm{IC}_{\mathbf{5 0}}$ ( $\boldsymbol{\mu \mathrm { gSe }} / \mathbf{m g}$ of Protein) \\
\hline JIMT-1 & 0.31 \\
\hline BT-474 & 3.03 \\
\hline
\end{tabular}

Figure 9. (a) $\mathrm{IC}_{50}$ calculations for Se-Trastuzumab treated JIMT-1 cells from Figure $8 \mathrm{~d}$ and (b) $\mathrm{IC}_{50}$ calculations for SeTrastuzumab treated BT-474 cells from Figure 8e. (c) The $\mathrm{IC}_{50}$ is calculated here for Se-Tz after treating the two cancer cell lines from low to high concentrations using the Graph Pad Prism software from 9a and 9b. 


\subsection{Scanning Electron Micrographs of JIMT-1 and BT-474 Cells}

JIMT- 1 and BT-474 cells seeded at the density of $1 \times 10^{5}$ cells/well in 24-well plates and treated with $\mathrm{Tz}, \mathrm{Se}-\mathrm{Tz}$ at $9.6 \mu \mathrm{gSe} /$ well and selenite at $10 \mu \mathrm{gSe} /$ well for $96 \mathrm{~h}$. Selenium treated and untreated cells were collected from the wells by pipette and were fixed in 10\% buffered formalin on glass coverslips followed by $4-5 \mathrm{~h}$ of air-drying. SEM images were taken at 5-20 $\mu \mathrm{m}$ and photos were stored on a Hitachi computer (Figure 10). Se-Tz and selenite treated cells demonstrated disrupted membranes in both cell lines as compared to Tz or control cells, which revealed smooth cellular membranes. Selenite treatment also demonstrated intense membrane disruption with loss of original cellular morphology as compared to control cells. More apparent cytotoxic effects of Se-Tz and selenite to cell morphology were visible in both JIMT-1 and BT474 cell lines, consistent with free radical generation of $\mathrm{O}_{2}{ }^{\bullet-}$ and $\mathrm{H}_{2} \mathrm{O}_{2}$ previously demonstrated and now visualized in the representative SEM micrographs (Figure 10).
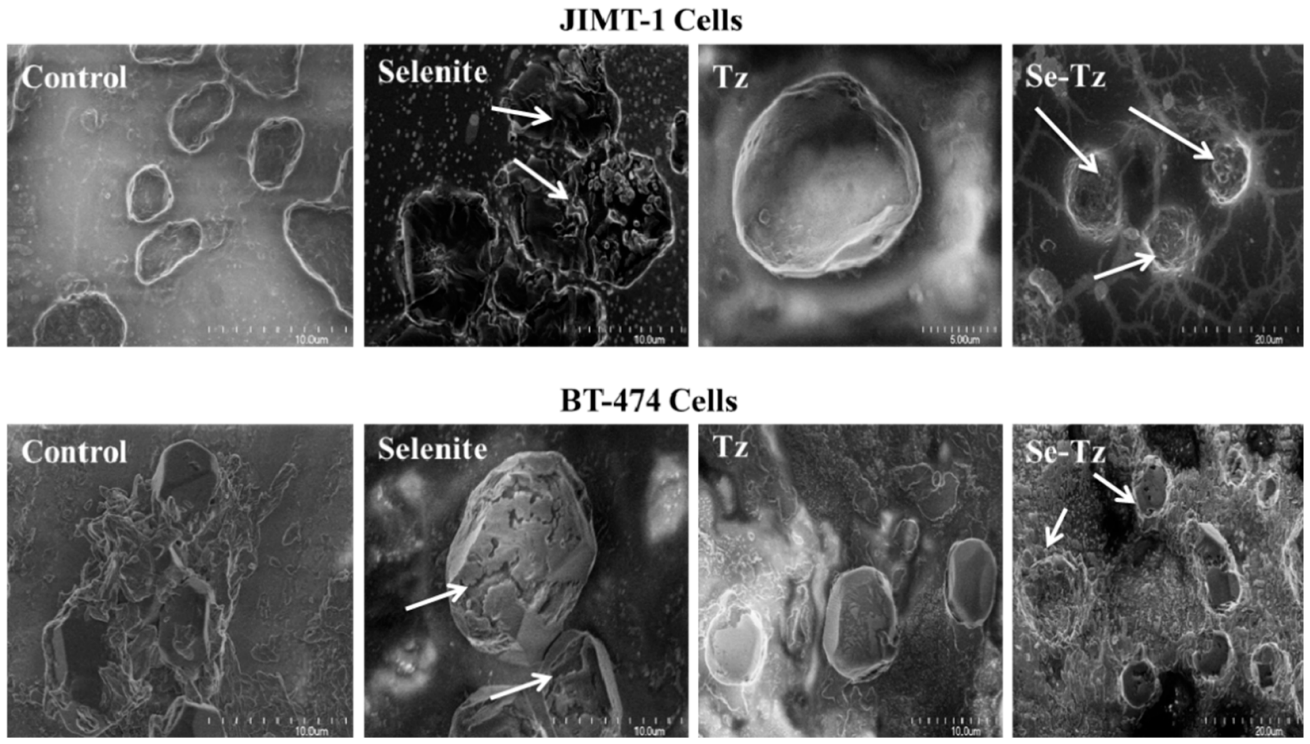

Figure 10. Morphology of control and selenium treated JIMT-1 and BT-474 cells by scanning electron microscopy. Representative control and Se treated cancer cells at $72 \mathrm{~h}$ were fixed in $10 \%$ buffered formalin on glass cover slips and allowed to air-dry for $4-5 \mathrm{~h}$. SEM images of both the cancer cell lines were taken using a Hitachi Model S-4700 FE-SEM at magnifications of 5-20 $\mu \mathrm{m}$ after $96 \mathrm{~h}$ of selenium treatment.

\section{Discussion}

Breast cancer remains the most common invasive cancer and cause of death among women, with 279,100 estimated new cases reported in 2020 and $~ 42,690$ deaths (ACS, Surveillance Data of Breast Cancer, 2019). Approximately 20-30\% of these breast cancers are Her/2+ [19] and, before the 1990s, women had poor survival rates as surgery was and remains a highly employed modality of prevention (i.e., BRACA) and treatment of breast cancer. With the discovery of the EGFR1 receptor, the Her/2 gene and the clinical development of monoclonal antibodies, in September 1998, the FDA approved the first clinical "neutralizing" mab to treat Her/2+ breast cancer, Trastuzumab (Tz), better known publically as Herceptin ${ }^{\circledR}$. Many women responding to Herceptin ${ }^{\circledR}$ treatment, a characteristic of the BT-474 cells used in this study, only have their cancer become resistant with disease progression $[19,20]$, more characteristic of the JIMT- 1 cells used in this study. In response to clinical $\mathrm{Tz}$ resistance, Genentech-modified $\mathrm{Tz}$ by the covalent addition of three or more molecules of the chemotherapeutic cytoskeletal inhibitor, emtansine. This first clinical Antibody-Drug Conjugate (ADC) T-DM-1, Kadcyla ${ }^{\circledR}$, significantly extended the survival of women with Her/2+ Tz resistant advanced breast cancer [20]. T-DM-1 was approved by the FDA in 2013 as the successor to the clinical use of Tz against Her/2+ 
breast cancer and patients receiving T-DM-1 treatment have shown disease free progression with improved survival rates [21,22]. Despite the treatment responses with T-DM-1, most patients eventually develop progressive disease with few patients showing long term stability with Her/2+ directed monoclonal breast cancer antibody therapy.

In this research we have sought to improve upon, compare and demonstrate improvement in cancer cell inhibition with Se-Tz treatments, compared to Tz treatments in vitro, against the Herceptin ${ }^{\circledR}$ susceptible BT-474 cells and the Herceptin ${ }^{\circledR}$ resistant JIMT-1 cells. This observational improvement is clearly demonstratable by Trypan Blue light microscopy of cell morphology, MTT and caspase-3 assays and SEM photographs. The difference between $\mathrm{Tz}$ and Se-Tz cancer cell growth inhibition is attributable to the covalent addition of selenium forming the colored Se-Tz derivative of Herceptin ${ }^{\circledR}$ shown in Figure 2. The covalent Se attachment transforms Herceptin ${ }^{\circledR}$ and other mabs, from being "neutralizing" mabs against Her $/ 2+$ cancer cells into a "cytotoxic" Se-ADC, catalytically generating superoxide, $\mathrm{O}_{2}^{\bullet-}$.

The Se-Tz generated $\mathrm{O}_{2}{ }^{\bullet-}$ is demonstrable in vitro by a Lucigenin Chemiluminescent Assay and ex vivo intracellularly by the florescent dye Dihydroethidium. $\mathrm{H}_{2} \mathrm{O}_{2}$ was also detectable ex vivo following selenium treatment of cell lines with Dichlorodiflurohydrazine when $\mathrm{H}_{2} \mathrm{O}_{2}$ was detected by DCFH-DA it was likely due to the intracellular reduction in the selenium generated $\mathrm{O}_{2}{ }^{\bullet-}$ by Se-Tz.

This research was conducted in a fashion similar to Goswami et al. [23] who reported on Se-Transferrin against leukemia cell lines and Khandelwal et al. for their comparison of Se-Herceptin ${ }^{\circledR}$, and Avastin ${ }^{\circledR}$ against Triple Negative Breast Cancer (TNBC) cell lines [24]. The experimental results observed herein and conclusions we draw from the present data are very similar to the conclusions drawn from the above referenced publications, [23] and [24] and they are:

(1) Redox selenium covalently attached to any mab generates $\mathrm{O} 2 \bullet-$., conferring the native mab, or protein, cytotoxic, as is selenite generating $\mathrm{O} 2 \bullet-$, used concurrently in experiments as a toxic positive selenium control;

(2) Se-Tz was more toxic to both cell lines, as was selenite, than Tz in a dose and time dependent manner across all measurements of cell morphology and metabolic viability;

(3) Se-Tz was $\sim 10 \mathrm{X}$ more cytotoxic (IC50) (Figure 9) to the Tz resistant JIMT-1 cells than the Tz susceptible BT-474 cells, (JIMT-1; $0.310 \mu g S e)$ and BT-474 (3.03 $\mu \mathrm{gSe})$ (Figure $9 \mathrm{c}$ ),

(4) Cell death from redox selenium being time and dose dependent is likely induced apoptosis from the oxidative stress of $\mathrm{O} 2 \bullet-$, being intracellularly generated by the oxidation of mitochondrial and cytoplasmic thiols;

(5) The collective data for Se-Tz treatments of the JIMT-1 and BT-474 cancer cells is fully consistent with the SEM cell data of Spallholz et al. [25] showing that only redox cycling selenium, superoxide $(\mathrm{O} 2 \bullet-)$ generating selenium compounds are cytotoxic to mammalian, bacteria and yeast cells [26,27].

In conclusion, this research has demonstrated Se-Tz synthesized from a coupling reaction from a Bolton-Hunter-like selenoester with Tz significantly decreased cell viability in Her / 2+ JIMT- 1 and BT-474 cell lines in a dose and time dependent manner $\left(^{* *} p<0.001\right.$, $* p<0.05)$. Trypan blue staining and an MTT assay at various Se-Tz concentrations demonstrated significant, ${ }^{*} p<0.05$ loss of JIMT-1 and BT-474 cell viability. The Caspase- 3 assay demonstrated that reduced cell viability of both Her/2+ cell lines was due to either extrinsic (death ligand) or intrinsic (mitochondrial) apoptotic pathways in both JIMT-1 and BT-474 cell lines $\left({ }^{*} p<0.05\right)$. Since Se redox chemistry is known to cause mitochondrial swelling [28] apoptosis is likely induced by redox selenium intrinsically. Moreover, the DHE assay demonstrated Se-Tz induced intracellular superoxide generation in JIMT-1 and BT-474 cells in a dose dependent manner $\left({ }^{*} p<0.05\right)$. These results suggest the possibility of a drug delivery system of redox Se by Trastuzumab to Her/2+ breast cancer patients before or after patients encounter resistance. In addition, conjugating redox selenium selenides to $\mathrm{Tz}$, and other proteins suggest a much wider application of this redox technology to other antibodies and targeting molecules. In the contemporaneous situation of COVID-19 the technology is 
suggestive that a SARS-CoV-2 mab with redox selenium could be employed with a more toxic viral capacity than with an S-protein or other neutralizing SAR-2 mabs alone.

Herceptin ${ }^{\circledR}$ is a registered trademark of Genentech (Roche) for Tz antibody.

\section{Materials and Methods}

\subsection{Reagents}

The $N$-hydroxysuccinimide ester of 3-selenocyanopropionic acid (a modified selenium Bolton-Hunter Reagent; BHR) was synthesized by Eburon Organics N. V., Belgium following a previously reported method $[23,29]$ by a $N, N^{\prime}$-dicyclohexylcarbodimide (DCC) assisted coupling reaction of $\mathrm{N}$-hydroxysuccinimide and 3-selenocyanopropionic acid. The final Se-BHR ester product has a brick red color (Figure 2a). Sodium selenite was from Sigma-Aldrich Chemical Company, St. Louis, MO, USA. All other chemicals were reagent grade or purchased as chemical kits from their respective manufacturers.

\subsection{Selenium Antibody Conjugation}

Selenium Analysis of Se-Tz and Tz followed by an In Vitro Chemiluminescent Assay for Superoxide.

Following Tz conjugation with redox selenium and dialysis, the $\mathrm{pH}$ was verified to be $\mathrm{pH}$ 7.4, and aliquots of Se-Tz and $\mathrm{Tz}$ sent to TraceAnalysis Inc. were determined by ICP-MS to contain $25.8 \mu \mathrm{gSe} / \mathrm{mg}$ protein and $<0.35 \mu \mathrm{gSe} / \mathrm{mg}$ protein, respectively. Both Se-Tz and Tz were assessed for their ability to generate $\left(\mathrm{O}_{2}{ }^{\bullet-}\right)$ using an in vitro Lucigenin Chemiluminescent assay (Figure 3 ) at $37^{\circ} \mathrm{C}$ degrees as previous described by Chen et al. [16].

\subsection{Cell Culture of Breast Cancer Cells}

JIMT-1 cells were purchased from Addexbio (Cat \#C0006005, San Diego, CA, USA) propagated and maintained in DMEM-F12 (ATCC Cat\# 11320-033, Manassas, VA, USA) with fetal bovine serum added to a final concentration of $10 \%$. BT- 474 cells were purchased from ATCC (Cat \# HTB-20, Manassas, VA, USA) propagated and maintained in RPMI 1640 media (ATCC Cat\# 30-2001, Manassas, VA, USA) with fetal bovine serum added to a final concentration of $10 \%$. Both cell lines (Figure 1) were grown in tissue culture flasks in a humidified atmosphere of $95 \%$ air and $5 \% \mathrm{CO}_{2}$ at $37^{\circ} \mathrm{C}$. Growth medium was renewed every 2 or 3 days and cell densities were maintained at $1 \times 10^{5}$ cells $/ \mathrm{mL}$ before passage. Under these incubation conditions it had been determined that after seeding of equal amounts of cells, the rates of cell division of the JIMT- 1 cells were $\sim 2$ X that of the BT-474 cells.

\subsection{Trypan Blue Viable Cell Assay}

Both cell lines were seeded in triplicates as described above at a concentration of $1 \times 10^{5}$ cells/well in 24-well plates. Upon the completion of the control and selenium concentration addition and treatment times as indicated in Figure $4 \mathrm{a}, \mathrm{b}$, photographs of the cells were taken at 20X magnification using an EVOS microscope (AMEX1000, Life Technologies, Grand Island, NY, USA) following addition of Trypan Blue, $10 \mu \mathrm{L} /$ well of the TB stock solution.

\subsection{Dihydroethidium (DHE), Dichlorofluorescein (DCFH-DA) and Caspase-3 Assays}

JIMT-1 cells were seeded in DMEM-F12 (Thermo Fisher Scientific Cat \# 21041-025) in phenol red free medium and BT-474 cells were seeded in RPMI 1640 (Sigma-Aldrich Cat \# R7509) phenol red free medium. Both cell lines were grown in triplicates to a density of $1 \times 10^{5}$ cells/well in 24-well plates. For the DHE, DCFH-DA and caspase-3 assays, JIMT-1 cells were seeded at a concentration of $2 \times 10^{5}$ cells/well and the BT-474 cells were seeded at a concentration $3 \times 10^{5}$ cells/well. The concentration of cells was different having determined, as noted above, that JIMT- 1 cells divide almost twice as rapidly as BT-474 cells. In triplicates, cells were treated with Se-Tz at Se concentrations between $0.6 \mu \mathrm{g}$ and $19.2 \mu \mathrm{gSe} /$ well for 24, 72,96 , and $120 \mathrm{~h}$. All experimental data with Se-Tz was compared to data from control cells, $\mathrm{Tz}$ treated cells, and cells treated with sodium selenite (10 $\mu \mathrm{gSe} /$ well). 


\subsection{Superoxide Detection Assay: Dihydroethidium (DHE)}

JIMT- 1 and BT-474 cells were seeded in triplicates at a density of $2 \times 10^{5}$ cells/well in 24-well plates. After acclimatization for $24 \mathrm{~h}, 50$ units/well of Superoxide dismutase (SOD) (Sigma-Aldrich Cat\# S7571, St. Louis, MO, USA) from bovine erythrocytes and 100 units/well of catalase from bovine liver (Sigma-Aldrich Cat\# C1345-1G, St. Louis, MO, USA) were added to all wells in media. All cells, control, Se-Tz, Tz, selenite along with a treatment blank, received DHE in media at a final concentration of $10 \mu \mathrm{M} /$ well. Cells were photographed at $4 \mathrm{X}$ and 20X $30 \mathrm{~min}$ after treatment with an EVOS microscope for the red fluorescence generated by $\mathrm{O}_{2}{ }^{\bullet-}$. Visual photography was immediately followed by measurement of fluorescence intensity using a fluorescence microplate reader (BioTekSynergy $\mathrm{H1}$, Winooski, VT, USA) with an excitation at $520 \mathrm{~nm}$ and emission at $610 \mathrm{~nm}$ (Figure 5).

\subsection{Hydrogen Peroxide Detection Assay: Dichlorodihydrofluorescein Diacetate (DCFH-DA)} Fluorescent Assay

JIMT- 1 and BT- 474 cells were seeded in triplicates at a density of $2 \times 10^{5}$ cells/well in 24-well plates. After acclimatization for $24 \mathrm{~h}, 50$ units/well of superoxide dismutase (SOD) (Sigma-Aldrich Cat\# S7571, St. Louis, MO, USA) from bovine erythrocytes and 100 units/well of catalase from bovine liver (Sigma-Aldrich Cat\# C1345-1G, St. Louis, MO, USA) were added to all wells in media. All cells, control, Se-Tz, Tz, selenite along with a treatment blank, received DCFH-DA in media (Sigma-Aldrich Cat\#4091-99-0, St. Louis, $\mathrm{MO}, \mathrm{USA}$ ) at a final concentration of $30 \mu \mathrm{M} /$ well. Cells were incubated with the dye for $15 \mathrm{~min}$ followed by media removal from each well. The cells were then photographed at $4 \mathrm{X}$ after 15-20 min of treatment incubation with an EVOS microscope for the green fluorescence generated by $\mathrm{H}_{2} \mathrm{O}_{2}$. Fluorescence intensity was read using a fluorescence microplate reader (BioTekSynergy H1, Winooski, VT, USA) with an excitation at $475 \mathrm{~nm}$ and emission at $525 \mathrm{~nm}$ (Figure 6).

\subsection{Apoptotic Assays: Caspase-3}

JIMT- 1 and BT- 474 cell lines were seeded in triplicate at a density of $3 \times 10^{5}$ cells/well in 24-well plates and incubated with Se-Tz, Tz and selenite treated cells for 24 and $72 \mathrm{~h}$, respectively. Control and treated cells were lysed with buffer (Abcam Cat\#39401 Cambridge, MA, USA) and protein concentrations were measured using the BCA kit (Pierce ${ }^{\mathrm{TM}}$ \#23225 Waltham, MA, USA). Cells were measured for caspase-3 by p-NA light emission at $405 \mathrm{~nm}$ using a microtiter plate (BioTek Synergy H1, Winooski, VT, USA) (Figure 7).

\subsection{MTT Cell Viability Assay}

Cells were seeded in triplicate in 24-well plates at a density of $1 \times 10^{5}$ cells/well and 3-[4, 5-dimethylthioazol-2-yl]-2-5-diphenyltetrazolium bromide (MTT) solution ( $5 \mathrm{mg} / \mathrm{mL}$ ) $10 \%(v / v)$ was added after treatment to each well (Figure $8 \mathrm{a}, \mathrm{b})$. The formazan generated by viable cells was solubilized by Tween- 20 and isopropanol $(1 \mathrm{~mL} /$ well $)$ and absorbances of the soluble formazan at 570 and $690 \mathrm{~nm}$ were recorded using a microplate reader (BioTek Synergy H1, Winooski, VT, USA).

\subsection{Se-Tz IC 50 Data}

The $\mathrm{IC}_{50}$ for Se-Tz treated JIMT- 1 and BT-474 cells was determined by using the cell viability data in dose response equations built into the Graph Pad Prism software and the graphs were plotted using Microsoft Excel (Figure 9).

\subsection{Scanning Electron Microscopy: Imaging}

JIMT- 1 and BT-474 cells were seeded at the density of $1 \times 10^{5}$ cells/well in 24-well plates followed by the treatments with Se-Tz at $9.6 \mu \mathrm{gSe} /$ well, Tz or selenite, $10 \mu \mathrm{gSe} /$ well. At $96 \mathrm{~h}$ post treatment, $20 \mu \mathrm{L}$ of cells was removed with an Eppendorf pipette and was fixed in PBS buffered (10\%) formalin (pH 7.4) on $2 \times 2 \mathrm{~cm}$ glass cover slips (Fisher brand Cat\#12-545-A, Pittsburg, PA, USA). The cells were allowed to air-dry for $4-5 \mathrm{~h}$ and images 
of cells were taken at 5-20 $\mu \mathrm{m}$ of magnification and saved on a computer from Hitachi, Model S-4700 FE-SEM (Wallingford, CT, USA) (Figure 10).

\subsection{Statistical Analyses}

All experimental assays were conducted in triplicate or more replications unless otherwise noted and are representative of three or more independent experiments. Statistical results are expressed as the Mean \pm one Standard Deviation (SD). Analyses were performed using the SPSS statistical software with two-tailed paired t-tests, an independent $\mathrm{t}$-test and one-way ANOVA. Significance between and among treatments is indicated in the text and Figures as $p<0.05\left(^{*}\right)$ and $p<0.001\left(^{* *}\right)$.

Author Contributions: Conceptualization, J.E.S. and M.B.; cell culture experiments and labeling experiments, P.B. and D.G.S.; Se-BHR synthesis, A.K.S.; resources, J.E.S. and A.K.S.; writing—original draft preparation of original manuscript, P.B.; writing - review and editing, J.E.S., A.K.S. and M.B.; supervision, J.E.S. All authors have read and agreed to the published version of the manuscript.

Funding: This research received no external funding.

Institutional Review Board Statement: Not applicable.

Informed Consent Statement: Not applicable.

Data Availability Statement: Not applicable.

Acknowledgments: This work was supported in part by The Department of Nutritional Sciences and the College of Human Sciences, Texas Tech University, Lubbock, TX, USA. Trastuzumab was kindly provided by Everardo Cobos of the TTUHSC Oncology Clinic. AKS thanks the Department of Pharmacology, Penn State College of Medicine, and Penn State Cancer Institute (PSCI) for financial support. The authors thank Organic Synthesis Shared Resource and Center for NMR Research Facilities of the Penn State College of Medicine.

Conflicts of Interest: The authors declare no conflict of interest.

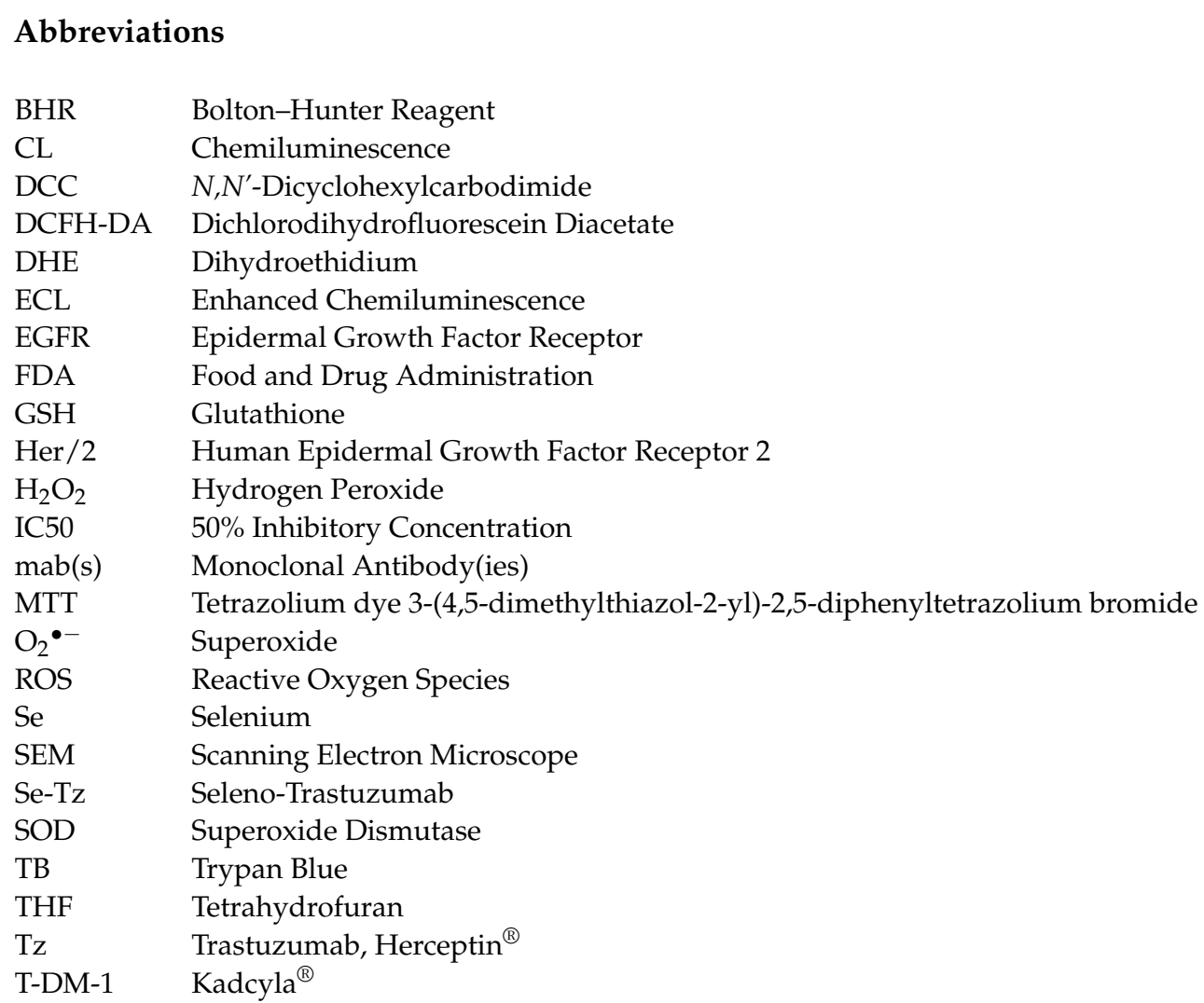




\section{References}

1. Carpenter, G.; King, L.; Cohen, S. Epidermal growth factor stimulates phosphorylation in membrane preparations in vitro. Nature 1978, 276, 409-410. [CrossRef]

2. Ullrich, A.; Coussens, L.; Hayflick, J.S.; Dull, T.J.; Gray, A.; Tam, A.W.; Lee, J.; Yarden, Y.; Libermann, T.A.; Schlessinger, J.; et al. Human epidermal growth factor receptor cDNA sequence and aberrant expression of the amplified gene in A431 epidermoid carcinoma cells. Nature 1984, 309, 418-425. [CrossRef] [PubMed]

3. Yokota, J.; Toyoshima, K.; Sugimura, T.; Yamamoto, T.; Terada, M.; Battifora, H.; Cline, M. Amplification of c-erbB-2 Oncogene in Human Adenocarcinoma In Vivo. Lancet 1986, 327, 765-767. [CrossRef]

4. Kraus, M.H.; Issing, W.; Miki, T.; Popescu, N.C.; Aaronson, S.A. Isolation and characterization of ERBB3, a third member of the ERBB/epidermal growth factor receptor family: Evidence for overexpression in a subset of human mammary tumors. Proc. Natl. Acad. Sci. USA 1989, 86, 9193-9197. [CrossRef] [PubMed]

5. Culouscou, J.M.; Plowman, G.D.; Carlton, G.W.; Green, J.M.; Shoyab, M. Characterization of a breast cancer cell differentiation factor that specifically activates the HER4/p180erbB4 receptor. J. Biol. Chem. 1993, 268, 18407-18410. [CrossRef]

6. Baselga, J.; Pfister, D.; Cooper, M.R.; Cohen, R.; Burtness, B.; Bos, M.; D’andrea, G.; Seidman, A.; Norton, L.; Gunnett, K.; et al. Phase I studies of anti-epidermal growth factor receptor chimeric antibody C225 alone and in combination with cisplatin. J. Clin. Oncol. 2000, 18, 904-914. [CrossRef] [PubMed]

7. Fiszman, G.L.; Jasnis, M.A. Molecular Mechanisms of Trastuzumab Resistance in HER2 Overexpressing Breast Cancer. Int. J. Breast Cancer 2011, 2011, 352182. [CrossRef]

8. Shawver, L.K.; Slamon, D.; Ullrich, A. Smart drugs: Tyrosine kinase inhibitors in cancer therapy. Cancer Cell 2002, 1, 117-123. [CrossRef]

9. Slamon, D.; Pegram, M. Rationale for trastuzumab (Herceptin) in adjuvant breast cancer trials. Semin. Oncol. 2001, 28, 13-19. [CrossRef]

10. Robertson, D. Genentech's anticancer mAb expected by November. Nat. Biotechnol. 1998, 16, 615. [CrossRef]

11. Albanell, J.; Baselga, J. Trastuzumab, a humanized anti-HER2 monoclonal antibody, for the treatment of breast cancer. Drugs Today 1999, 35, 931-946.

12. Ballantyne, A.; Dhillon, S. Trastuzumab emtansine: First global approval. Drugs 2013, 73, 755-765. [CrossRef] [PubMed]

13. True, C.D. Preparation of an Iodinated Radioligand. Curr. Protoc. Neurosci. 2001, 1, A.3A.1-A.3A.6. [CrossRef]

14. Chaudiere, J.; Courtin, O.; Leclaire, J. Glutathione oxidase activity of selenocystamine: A mechanistic study. Arch Biochem. Biophys. 1992, 296, 328-336. [CrossRef]

15. Seko, Y.; Imura, N. Active oxygen generation as a possible mechanism of selenium toxicity. Biomed. Environ. Sci. 1997, 10, 333-339. [PubMed]

16. Chen, J.J.; Boylan, M.; Wu, C.K.; Spallholz, J.E. Oxidation of glutathione and superoxide generation by inorganic and organic selenium compounds. BioFactors 2007, 31, 55-66. [CrossRef] [PubMed]

17. Lin, Y.; Spallholz, J.E. Generation of reactive oxygen species from the reaction of selenium compounds with thiols and mammary tumor cells. Biochem. Pharmacol. 1993, 45, 429-437. [CrossRef]

18. Nagy, P.; Friedländer, E.; Tanner, M.; Kapanen, A.I.; Carraway, K.L.; Isola, J.; Jovin, T.M. Decreased accessibility and lack of activation of ErbB2 in JIMT-1, a herceptin-resistant, MUC4-expressing cancer cell line. Cancer Res. 2005, 65, 473-482. [PubMed]

19. Nahta, R.; Esteva, F.J. Trastuzumab: Triumphs and tribulations. Oncogene 2007, 26, 3637-3643. [CrossRef] [PubMed]

20. Nahta, R.; Yu, D.; Hung, M.C.; Hortobagyi, G.N.; Esteva, F.J. Mechanisms of disease: Understanding resistance to HER2-targeted therapy in human breast cancer. Nat. Clin. Pract. Oncol. 2006, 3, 269-280. [CrossRef]

21. Burris, H.A.; Tibbitts, J.; Holden, S.N.; Sliwkowski, M.X.; Phillips, G.D.L. Trastuzumab emtansine (T-DM1): A novel agent for targeting HER2+ breast cancer. Clin. Breast Cancer 2011, 11, 275-282. [CrossRef]

22. Krop, I.E.; Beeram, M.; Modi, S.; Jones, S.F.; Holden, S.N.; Yu, W.; Girish, S.; Tibbitts, J.; Yi, J.H.; Sliwkowski, M.X.; et al. Phase I study of trastuzumab-DM1, an HER2 antibody-drug conjugate, given every 3 weeks to patients with HER2-positive metastatic breast cancer. J. Clin. Oncol. 2010, 28, 2698-2704. [CrossRef]

23. Goswami-Sewell, D.; Bapat, P.; Boylan, M.; Spallholz, J.E. In Vitro Cytotoxic Effects of Control and Selenium Conjugated Transferrin's against Leukemia Cell Lines K562 and THP-1. Biomed. J. Sci. Tech. Res. 2019, 13. [CrossRef]

24. Khandelwal, S.; Boylan, M.; Spallholz, J.E.; Gollahon, L. Cytotoxicity of Selenium Immunoconjugates against Triple Negative Breast Cancer Cells. Int. J. Mol. Sci. 2018, 19, 3352. [CrossRef] [PubMed]

25. Spallholz, J.E.; Freitas, R.; Whittam, J. Cytolytic Activity of Selenium Compounds and Glutathione Peroxidase Assessed by Scanning Electron Microscopy. Fed. Proc. 1982, 41, 529.

26. Brigelius-Flohe, R.; Sies, H. Diversity of Selenium Functions in Health and Disease; CRC Press: Boca Raton, FL, USA, $2015 ;$ Volume 83.

27. Spallholz, J.E. On the nature of selenium toxicity and carcinostatic activity. Free Radic. Biol. Med. 1994, 17, 45-64. [CrossRef]

28. Levander, O.A.; Morris, V.C.; Higgs, D.J. Acceleration of Thiol-Induced Swelling of Rat Liver Mitochondria by Selenium. Biochemistry 1973, 12, 4586-4590. [CrossRef] [PubMed]

29. Bolton, A.E.; Hunter, W.M. The labeling of proteins to high specific radioactivity by conjugation to a ${ }^{125} \mathrm{I}$-containing acylating agent. Biochem. J. 1973, 133, 529-539. [CrossRef] 